\title{
Reform of the Electronic Innovation Applied Talents Training System
}

\author{
H.W. QIN, H.X. ZHANG, J. LI, M. Zhang \& X.J. LI \\ College of Electronic and Information Engineering, Changchun University, Changchun, China
}

\begin{abstract}
As a local college engineering professional, how to grow according to the needs of engineering students to construct appropriate educational environment, the implementation of engineering innovation education reform experiments, training meet the social needs of the high-level application-oriented talents, is the major opportunities and challenges we face. Accorded to college "application-oriented college" personnel training orientation, training target application electronic innovations senior technical personnel system reform for professional practice, to explore a training model engineering ability and quality of transport solid foundation for society and local, strong practical ability, there are high-level sense of team applied talents. KEYWORD: Innovative Practice; Practice Teaching Mode; Evaluation System; Simulation Development
\end{abstract}

\section{INTRODUCTION}

Students from the Practice Innovation Technology Competition and Engineering Project three aspects Cultured students engineering practice innovation capability, exploring and implementing engineering practice ability of applied electronics innovative training model of the main line[1-3]. Content reforms and measures: to achieve training objectives for the guidelines, research the following:

1) To build New Practical Teaching System of Innovation;

2) Reform of assessment methods, innovative practice teaching process management;

3) Competition for training, encourage students to participate in science and technology competition and technological innovation;

4) Reform of Practice Teaching Mode.

Training mode reference advanced engineering education practice teaching, practice teaching hierarchical structure training system: according to aspects of the practice of project conception, design, implementation, operation of four levels of steps designed to enhance students' innovative practice progressively engineering capabilities; Experiment System from the simple "verification" experiment to "analyze the design and system integration" experimental direction of change, a lot of the development of comprehensive and designed experiments; advocating academic competitions as the carrier, the traditional curriculum choices, new technologies, new theories supplement reasonable increase in practice hours, reducing the theoretical lessons [4-6].

Research methods and procedures: Construction of a new system of teaching practice $\rightarrow$ Integration of experimental courses $\rightarrow$ Curriculum design reform $\rightarrow$ Training reform $\rightarrow$ Graduation design reform $\rightarrow$ Reform of Teaching Examination $\rightarrow$ Competition for training $\rightarrow$ Reform of practice teaching mode.

\section{REFORM OF PRACTICE TEACHING MODE}

Reform of experimental teaching methods, change "passive practice" for the "active practice". In order to change the students' passive practice "status, you can experiment teaching methods reform. Before the experiment, to provide students with "experimental mission statement", with "experimental mission statement" instead of "experimental guide book", that only gives the basic requirements of the experiment, the necessary equipment and experimental considerations [7]. The specific experimental methods, procedures and laboratory equipment, instrumentation choices available, entirely by the students before the experiment done by drafting a detailed report on the experimental rehearsal.

Innovative practice teaching process management. Establish each student from freshman to senior practice files for information on student four years practical experience formed, the teacher 
reviews each event, corporate evaluation, employment and entrepreneurial process, practice effects were recorded; established practice teaching management file, the uniform assessment methods, syllabus practice, practice teaching plans and instructions included in the system, such as the overall management; established practice teaching teachers archives, collection companies, students, department heads and teachers suggested follow-up activities proposed practical teaching suggestions for improvement; established practice base case files, collection companies, business leaders to fulfill the contract, selected teachers and other business practices [8-9]. Establish quality monitoring and evaluation system. According to the practice of teaching objectives, contents, outline the establishment of a new assessment, evaluation system. To strengthen the practical teaching process checks, focusing on practical teaching content is comprehensive examination, whether the design standards, whether advanced teaching methods and means, so as to avoid the formality, practice teaching unorganized and other phenomena.

Competition for training, encourage students to participate in science and technology competition and technological innovation. Practice is the source of innovation, academic competitions are provided to the students to join the practice, the opportunity to solve practical problems [10]. By academic competitions to test the quality of talent back to the practice of reform in order to promote the reform of the curriculum system and teaching content, stimulate students' enthusiasm and innovation. Unlike academic competitions unusual tournament title examination, it comes from the actual problem or very close to actual engineering projects. Topics such as electronic design contest, both theoretical design but also the actual production. To complete such a race issue, we must first have a solid theoretical foundation, but also have strong hands-on capability, which provides a full play to the students' ability of independent innovation room. By participating in the competition, creating the potential and ability to innovate are also in the process of solving the problem got excited, so that the theoretical knowledge and practical ability of college students have been improved to some extent.

Extracurricular Scientific Activities on expanding student knowledge track the latest achievements of science and technology; improve the overall quality of students, students' practical ability and innovative spirit of great significance. We have designed Extracurricular Scientific Activities included three aspects: First, learn academic science and technology, and second, innovative academic technology, the third is the application of academic science and technology, these three aspects constitute a complete system of academic science and technology activities of university students.
These three aspects may also exist and play a role in each other; the ideal state is to promote the formation of interactive mechanism to promote learning in-depth, innovative active applications widely

\subsection{To Build New Practical Teaching System Innovation}

The academic competitions and school-related professional practice content closely, help to promote the practice of reform and innovation laboratory construction work is a way for students to improve learning initiative, broaden their knowledge, and a good way to effectively enhance innovation capability, also to promote the overall development of students, training students' comprehensive quality important carrier. Electronic innovative training processes are shown in figure. 1.

(1) The experimental curriculum reform: reform in the past course experiment with curriculum as the theme, the core of knowledge among the various professional courses fragmentation, there is no uniform training objectives and disadvantages of the overall optimization of the proposed curriculum plate experiments. Set the plate of the pilot project to the interlink ages between professional core courses and elective courses appropriate knowledge of the principles, emphasizing the idea of project-based experiments, design, implementation, operation, so that the experiment really play a role in curriculum design and operation of personal;

(2) Curriculum design reform: In accordance with the limits for a training model, knowledge and time, we put the contents of the curriculum design direction as a professional design the main line through the contents of all courses, complete a full project design process. The core idea of the project is designed to encourage students to be active learning and integrated learning, academic research activities to promote student learning in the curriculum design project system construction, model analysis, algorithm comparison, simulation development, scientific conclusions analysis skills; teachers in the design only play a guiding role, inspire students' creative thinking through seminars, technical seminars, programs and other forms of research;

(3) Training reform: we follow the course of the training personnel training is divided into three categories: training courses, training programs and business training, three kinds of training are conducted in teams. Training courses are conducted primarily for the purpose of learning training courses under the guidance of teachers, curriculum and grasp the knowledge points standing argument by training project; project training is to simulate the actual project development model, the project manager (instructor) under the guidance of the training course 
design projects for each school semester. All grades of project training is different, are problem solving, implementation requirements, and make products for the purpose. Corporate training in all courses after the third grade, before internship, the students sent to the company in accordance with the employee's request to do a project, from design and development to deliver a comprehensive assessment of the student can become a qualified staff;

(4) Reform of graduation design: a university graduate design process last only a part of a comprehensive training and test students' professional qualities and engineering practice ability. Teachers should be closely integrated research project or topic, select the topic from valuable research task to design, test and research; encourage students from the employer for the actual engineering topics to do graduate design, and employers using the method of parallel design, inspection graduation design effect. So we thought based on engineering education, implementing a "production, learning and research," a combination of patterns to organize and manage design graduate teaching process, the establishment of the "three links" management model.

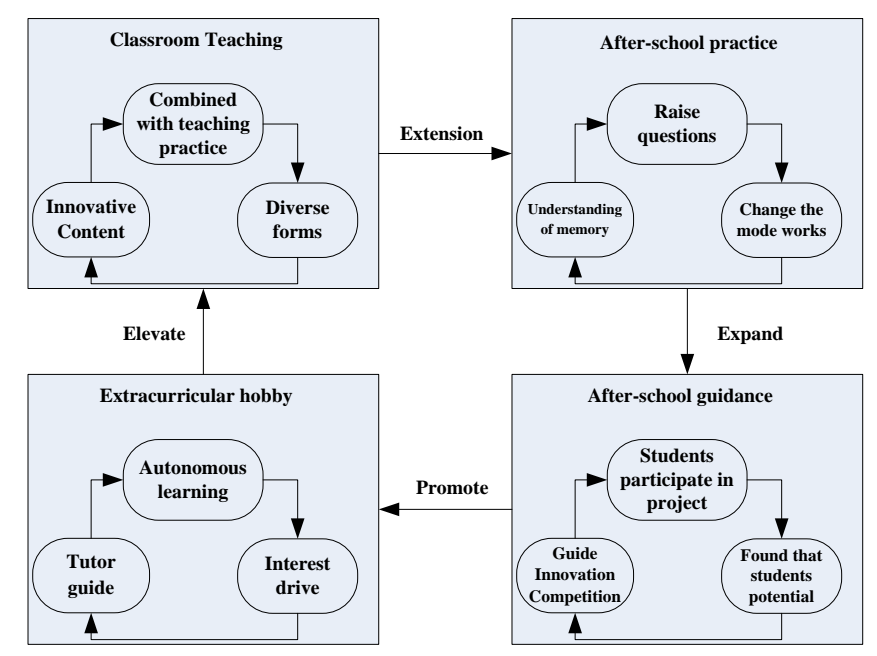

Figure1. The block diagram of electronic innovative training processes

Students planning innovative practice base construction program is to make the goal of building concrete process is to improve the bases of an important part. In the planning process should focus on the goal of building and construction ideas, will foster innovation and comprehensive design capabilities and engineering practice ability throughout the whole process of teaching. In this process, you should expose students to create outstanding examples of the invention and abroad, in order to inspire awareness of innovation, break the mystery and desire to stimulate the creation of inventions, so that students disassembly and mapping of a typical system, functional analysis, schematic analysis, configuration analysis and structural expression, innovative simulation techniques, integrated innovative learning methods, according to the design requirements for students, with the help of advanced modern design tools for creative design, and the design of computer simulation and emulation to improve the overall design capabilities, create conditions for students to design their own programs modeled dematerialized or overlapping parts of the assembly, in order to verify the reliability of their own design, exercise ability and the ability of engineering practice, to have had the products or their innovative design for performance experiments to understand the impact of various factors performance measures to improve the design proposed to improve entrepreneurial capacity. This is a complete training process, innovative practice bases Students said the training process is to provide an environment of experimentation and practice.

\section{CONCLUSIONS}

Reform and practice of applied talents training of electrical engineering and automation enabled students to have a solider foundation theory and practical skills, to made professional knowledge closer to the actual job; it gave full play to the three party comprehensive affect among the school, students and businesses, formed applied talents training mode with characteristics of power industry.

Increase classroom practice teaching. Classroom practice teaching mode mainly discusses style, problem-based, inquiry-based teaching practice as the main way to enhance the interaction between teachers and students.

Increase the practical teaching emulation mode. The main idea is to take, simulation, special investigations, designed to discuss other ways. You can also use modern teaching methods were practical ability training. Such as the use of video, audio, courseware, networks, and other resources for comprehensive experimental discussions and training.

Hierarchical model established practice teaching, practice project by the conception, design, implementation, operation of four levels of step designs. Four designs contain a conceptual and practical understanding and innovation, science and technology for a variety of constraints and nontechnological understanding and compromise, and the practical ability to improve the product and improve the design and implementation of reflection effect.

\section{ACKNOWLEDGEMENTS}

In this paper, the research was sponsored by Jilin 
Provincial Education and Science Department (Project No. GH13053, GH14263). The research activities have been funded by Provincial Education and Science Department (Project No. GH12041). The research activities also have been funded by Jilin Provincial Education Department (Project No. SJZD12-02).

\section{REFERENCES}

[1] Xiaobin Zeng. Deeping Experiment and Practice Teaching Reform and Improving the Cultivation Quality of Application-oriented Talents.. Research and Exploration in Laboratory, 2010, (2):1-3. (CH)

[2] Xiaoying $\mathrm{Yu}$. Training of Innovative Talents and Reform of Practice Teaching.. Lab technology and management, 2010 (5):30-32. (CH)

[3] Xinfeng Fu, Changnian Zhang. Construction of Practical Teaching System for Applied Talents. Research and Exploration in Laboratory, 2011 (6):148-150. (CH)
[4] Zhou peisong. The College Students Investigate Scientific and Technological Innovation. Technology-based Business Monthly, 2006 (12): 101-103. (CH)

[5] Zheng Meiling. The Present Position of the Students in Extra-curricular Academic Science and Technology Activities. Youth to Explore, 2005 (5):132-135 (CH)

[6] Ma Jianxin. Discussing Students' Ability in Scientific and Technological Innovation. Heilongjiang Higher Education Research. 2006 (10):156-158. (CH)

[7] Ke Gong. Thinking and Exploration of the cultivation of excellent engineers. China University Teaching, 2010, (8): 4-5. $(\mathrm{CH})$

[8] R.A. Aghaa, A. Papanikitasb, M. Baumc, The teaching of surgery in the undergraduate curriculum reforms and results. International Journal of Surgery, 2005, 3(1):8792.

[9] Higher Education Evaluation Center Of The Ministry Of Education, Explore the new model and the new mechanism - Independent Colleges experience revelation. Beijing: Higher Education Press, 2005.

[10] Zheng Rongjin, Huang Jiashan, Chen Xingwu. Research and practice of training electrical engineering and automation talents. China Power Education, 2008, 12 (7):54-56. (CH) 